\title{
Die hantering van neweskikkers en onderskikkers in Afrikaanse woordeboeke
}

\author{
Nerina Bosman, Departement Afrikaans, Universiteit van Pretoria, \\ Pretoria, Suid-Afrika (nerina.bosman@up.ac.za) \\ en \\ Anna N. Otto, Departement Taal en Lettere, NMMU, Port Elizabeth, \\ Suid-Afrika(anna.otto@nmmu.ac.za)
}

Opsomming: Die diskrepansie tussen die behoefte aan leksikografiese leiding met betrekking tot voegwoorde en die relatiewe onverskilligheid hierteenoor in terme van leksikografiese navorsing en praktyk het tot hierdie artikel aanleiding gegee, waarin die onbevredigende hantering van voegwoorde in Afrikaanse woordeboeke aangedui word en enkele konstruktiewe leksikografiese oplossings vir die hantering van hierdie woordsoortkategorie aan die hand gedoen word.

'n Eerste aanbeveling is dat die lemmata voegwoord, verbindingswoord, neweskikker, onderskikker en voegende bywoord meer diepgaande sintaktiese inligting, met genoeg voorbeelde (ook oor sinsgrense heen) voorsien. Daar behoort kruisverwysings van die spesifieke voegwoordlemmata na hierdie lemmata te wees. Die voorbeelde wat aangebied word, behoort ook tipiese leksikale en grammatiese patrone aan te dui, sowel as of hipotaktiese binding moontlik is of net inlywing. In aanleerderwoordeboeke kan die tipiese leksikale patrone in vet druk verskyn. Sorg moet gedra word in omvattende woordeboeke, soos WAT, om vinniger inligtingsherwinning tot gevolg te hê en leksikograwe behoort nie funksies gelyk te stel aan polisemiese betekenisonderskeidings nie. So is daar byvoorbeeld twee lemmas nodig by of aangesien dit ' $n$ homoniem is wat duidelik aparte lemmas vereis.

Sleutelwoorde: LEKSIKOGRAFIE, NEWESKIKKER, KORRELATIEWE NEWESKIKKER, ONDERSKIKKER, EENTALIGE WOORDEBOEK, HIPOTAKTIESE BINDING, INLYWING, KOMPLEMENTSINNE, GRAMMATIKALE LEIDING, LINGUISTIESE FUNDERING, WOORDORDE, KLOUSINTEGRASIE, FUNKSIEWOORD

\begin{abstract}
The Treatment of Coordinating and Subordinating Conjunctions in Afrikaans Dictionaries. Prompted by the discrepancy between the needs for lexicographic assistance with regard to conjunctions and the relative indifference concerning this in lexicographic research and practice, this study attempts to indicate the unsatisfactory treatment of conjunctions in Afrikaans dictionaries and to offer some constructive lexicographic solutions to the treatment of this part of speech category.

A first recommendation would be that the lemmata voegwoord (conjunction), verbindingswoord (connective), neweskikker (coordinating conjunction), onderskikker (subordinating conjunction) and voegende bywoord (conjunctional adverb) provide more in-depth syntactic information with enough examples (also across sentence boundaries). There should be cross-references from the specific con-
\end{abstract}


junction lemmata to these lemmata. The examples provided should indicate typical lexical and grammatical patterns and whether only hypotactic binding is possible or whether incorporation is also possible. In learners' dictionaries the typical lexical patterns can be in bold print. Care should be taken in inclusive dictionaries, like $W A T$, to promote faster information retrieval and lexicographers should not equate functions with polysemous meaning distinctions, e.g. there should be two lemmata for of as it is a homonym which clearly requires separate lemmata.

Keywords: LEXICOGRAPHY, COORDINATING CONJUNCTION, CORRELATIVE COORDINATING CONJUNCTION, SUBORDINATING CONJUNCTION, MONOLINGUAL DICTIONARY, HYPOTACTIC BINDING, INCORPORATION, COMPLEMENT SENTENCES, GRAMMATICAL GUIDANCE, LINGUISTIC GROUNDING, WORD ORDER, CLAUSE INTEGRATION, FUNCTION WORD

\section{Agtergrond en probleemstelling}

Sedert die verskyning van die twee artikels deur Gouws (1992 en 1998) oor neweskikking en die leksikografiese bewerking van neweskikkers, het min nog verander in die hantering van hierdie woorde in Afrikaanse woordeboeke. Indien ' $n$ mens byvoorbeeld kyk na die groot aantal woordordefoute wat sowel moedertaalsprekers as niemoedertaalsprekers maak met betrekking tot hierdie woordsoortkategorie, dwing dit mens om weer indringend te kyk na die rol wat die leksikograaf moontlik kan speel om duideliker leiding te gee in hierdie verband. Soos die navorsers hieronder sal aantoon, is die huidige hantering van bepaalde verbindingswoorde in Afrikaanse woordeboeke tot 'n hoë mate nog ewe onbevredigend as in 1992. Daardeur word hulle taalkundige gehalte in die gedrang gebring (Gouws 1992: 103) en gee hulle nie die regte leiding aan gebruikers nie.

Die feit dat daar nie genoeg aandag geskenk word aan verbindingswoorde nie, kan miskien toegeskryf word aan die tradisionele onderskeid tussen grammatika en leksikon, die woordgerigte benadering en die tipiese mikrostruktuur van leksikale morfeme in Afrikaanse verklarende woordeboeke. Grammatikale aspekte kry relatief min aandag en die hooffokus van die definiensgleuf gaan gepaard met 'n sterk teenwoordigheid van semantiese inligting by veral leksikale morfeme. Alhoewel Béjoint (2000: 6) byvoorbeeld die presisering van betekenis as die belangrikste oogmerk van die leksikograaf beskou en die gemiddelde woordeboekgebruiker veral op soek is na betekenisinligting (AlKasimi 1977), is dit natuurlik ook so dat die leksikografiese praktyk met die insluiting van grammatiese inligting wel die noue integrasie van grammatika en betekenis erken. Hartmann (1982: 83) toon in dié verband aan dat woordeboekgebruikers dikwels juis grammatikale inligting by grammatikale morfeme (of funksiewoorde) soos voorsetsels en verbindingswoorde verlang. Sinclair (1984: 4) wys ook daarop dat grammatikale inligting deel van die fundamentele inligting is wat ' $n$ woordeboek aanbied. Daar moet in gedagte gehou word dat verskillende tipes woordeboeke verskil betreffende die hoeveelheid 
en diepte van inligting wat deur die teikengebruiker vereis of gevra word vergelyk Gouws (1989: 209). Gouws merk elders op: "Die aard en omvang van die inligting word bepaal deur die tipe woordeboek maar ook deur die tipe leksikale item wat as lemma optree. (...) die leksikograaf (moet) besef dat verskillende lemmatipes telkens 'n eiesoortige bewerking moet kry" (Gouws 1992: 91).

Soos die navorsers verderaan sal aantoon, verdien verbindingswoorde se grammatikale gedrag meer aandag in Afrikaanse woordeboeke as wat hulle tans ontvang. Aangesien neweskikkers en onderskikkers so verskillend optree, kan hulle volgens Gouws (1992: 93) as aparte kategorieë beskou word en behoort hulle as sodanig in woordeboeke aangedui te word. Hierdie onderskeid word wel (maar nie deurgaans konsekwent nie) getref in die aanleerderwoordeboek Basiswoordeboek van Afrikaans, (voortaan $B A$ ) maar nie in die HAT, WAT of Pharos Verklarende Afrikaanse Woordeboek (voortaan PVAW) nie.

Tipies vir grammatikale morfeme is dit voorts moeilik om 'n betekenisdefinisie en fyner polisemiese onderskeidings vir verbindingswoorde aan te toon. Daar word tereg deur Gouws (1992: 98) gewys op die feit dat verbindingswoorde se belangrikste taalkundige kenmerke en funksie is dat hulle voeg (die navorsers se beklemtoning) en dat hoe en wat hulle voeg prominenter aangedui behoort te word in woordeboekartikels as byvoorbeeld betekenisinligting. Hulle funksie behoort dus meer prominensie te kry en dit sou selfs dié riglyn vir die strukturering van hulle woordeboekinskrywings kon wees.

Die probleem waarop hierdie artikel fokus, is dat 'n geslote klas soos verbindingswoorde sowel semanties as sintakties 'n bepaalde eiesoortige gedrag vertoon, maar dat hierdie eiesoortigheid nie tans bevredigend in woordeboeke verreken word nie. Ons poog in die artikel om die eiesoortige karakter van newe- en onderskikkers teoreties te belig en die huidige hantering van hierdie woorde in Afrikaanse verklarende woordeboeke te ondersoek. Ten slotte bied ons aanbevelings aan vir verbeterde leksikografiese praktyk.

\section{Metodologie}

Vir die teoretiese raamwerk wat ons voorstel onderlê, maak ons gebruik van insigte uit meer as een linguistiese benadering, insluitende die beskrywende en strukturele linguistiek, Halliday en Hasan se werk oor kohesie, die funksionele sistemiese grammatika en kognitiewe linguistiek, soos onder andere verteenwoordig deur Halliday en Hasan (1976), Ponelis (1979), Langacker (1987), Matthiessen en Thompson (1988), Gouws (1992), Bosch (1997), Bosch (1998), Verhagen (2001), Taylor (2002) en Halliday en Matthiessen (2004). Hierdie werkwyse is weliswaar taamlik eklekties, maar as sodanig nie ongewoon binne die leksikografiese tradisie nie - veral sover dit die aanvaarding en gebruik van verskillende erkende linguistiese konsepte betref. Op dié manier probeer ons om die linguistiese fundering van ons argument duidelik te maak - iets wat nie noodwendig altyd die geval is binne die leksikografie nie. 
Teen hierdie agtergrond sal die hantering van verbindingswoorde in drie verklarende woordeboeke, naamlik WAT, HAT en PVAW en een aanleerderwoordeboek, $B A$ krities ondersoek word.

Laastens sal sekere algemene beginsels en riglyne voorgestel word vir ' $n$ alternatiewe en meer optimale leksikografiese hantering van verbindingswoorde as 'n aparte en unieke woordklas. Hierde beginsels sal met behulp van die verbindingswoorde $\mathrm{d} a t_{\text {s }}$ of en of $\ldots$ of geïllustreer word.

\section{Teoretiese kontekstualisering}

Tradisioneel word daar in die Afrikaanse taalkunde 'n kategorie voegwoord onderskei waaronder neweskikkers, onderskikkers en voegende bywoorde ingedeel word (vergelyk De Villiers 1983: 61). Die tipes "voegwoorde" word in die eerste plek onderskei op grond van die aard van die integrasie tussen die sinne wat verbind word. Daarmee gepaardgaande het die gebruik van 'n spesifieke woord bepaalde implikasies vir die woordvolgorde van die sin wat geïntegreer word.

\subsection{Newe- en onderskikkers - terminologiese standpuntinname}

In die Afrikaanse linguistiekliteratuur word 'n hele aantal terme gebruik wat essensieel dieselfde funksie aandui en dieselfde tipe grammatikale morfeem of funksiewoord beskryf, soos onder andere: ${ }^{1}$ bindwoord, verbinder (Ponelis 1979: 313), verbindingspartikel (Bosch 1984: 18), verbindingswoord (Carstens 1997: 263), verbandswoord (Wybenga 1989: 189), en konjunksiemerker (Carstens 1997: 262). Carstens (1997: 263) meld ook terme soos junctions, junctive expressions, connectives en connectors wat in die Engelstalige literatuur gebruik word. Die bekendste term is sonder twyfel voegwoord, ${ }^{2}$ alhoewel Ponelis (1979) reeds daarop wys dat voegwoord tradisioneel slegs gebruik word waar ' $n$ bysin ingelyf word.

In navolging van Gouws (1998) stel die navorsers voor dat die term voegwoord vermy word. Dit word vervang met die meer neutrale term verbindingswoord. As gevolg van die fundamentele verskille (sowel semanties as sintakties) tussen die drie soorte verbindingswoorde wat tradisioneel onder dié term ingesluit word, sal ons so ver moontlik die terme neweskikker en onderskikker gebruik, asook die term voegende bywoord waar nodig.

\subsection{Kort kenskets}

Verbindingswoorde bewerkstellig integrasie tussen konjunkte. Klousintegrasie het enersyds te make met die graad van interafhanklikheid tussen konjunkte en andersyds ook met die logies-semantiese verhouding tussen hulle (Langacker 1987: 373). 
Die aspek van verbindingswoorde wat die moeilikste is om te definieer, is hulle semantiese inhoud omdat dit afhanklik is van die hele konstruksie waarvan hulle deel vorm. Feitlik alle verbindingswoorde dui 'n semantiese verhouding tussen tekselemente aan. In die meeste gevalle kan mens poog om hierdie verhouding te definieer - aaneenskakelend, alternerend, teenstellend, kousaal, temporeel, redegewend en so meer. In (1) en (2) word 'n kousale verhouding byvoorbeeld aangedui:

(1) Die krieketwedstryd is gestop want dit het begin reën.

(2) Die krieketwedstryd is gestop omdat dit begin reën het.

Die verhouding tussen die konjunkte kan nie altyd onder woorde gebring word nie - die onderskikker dat is hier die prototipiese voorbeeld. Soos later in 'n paragraaf oor leksikografiese bewerking sal blyk, hou die gesprek rondom die semantiese status van verbindingswoorde implikasies in vir die leksikografiese praktyk (Gouws 1992).

Morfologies gesproke vertoon verbindingswoorde geen variasie nie. Samestellings met dat soos voordat, nadat, totdat, omdat, ensovoorts is hier die uitsondering.

As mens na die groep verbindingswoorde kyk, is twee aspekte meer prominent as ander, naamlik die funksie wat hulle verrig, ('n voegfunksie) en die invloed wat hulle op die sintaktiese struktuur van die sin uitoefen - wat op sy beurt die gevolg is van die graad van integrasie wat bewerkstellig word. Hulle hooffunksie is om woorde, frases of klouse te verbind en om kohesie tussen teksdele tot stand te bring. ${ }^{3}$

Daar moet in die leksikografiepraktyk deeglik kennis geneem word van die rol wat verbindingswoorde vervul om koherente stukke teks te produseer - nie alleen binne sinsgrense nie, maar ook in groter teksgehele. (Vir ' $n$ bespreking van die sintaktiese funksies van voegwoorde binne sinsgrense versus diskoersfunksies oor sinsgrense heen, vergelyk Blühdorn (2008).) Sonder hierdie koherensie is 'n teks nie ' $n$ teks nie. In Halliday en Hasan se definisie verteenwoordig verbindingswoorde semantiese skakels tussen elemente wat ' $n$ teks opbou (Halliday en Hasan 1976: 226, 321). Daar is 'n aspek van teksbetekenis - die interpretatiewe verband - wat nie in terme van die betekenis van die dele van die teks beskryf kan word nie. Hierdie verband kan trouens tot stand gebring word sónder die gebruik van spesifieke leksikale items soos verbindingswoorde - koherensie kan bestaan sonder dat dit leksikaal gemarkeer is:

(3) Gee bietjie die tang aan, die spyker sit nogal vas. (voorbeeld van Verhagen 2001: 108).

In (3) moet die luisteraar self die korrekte verband tussen die konjunkte aflei, maar teksproduseerders kan hierdie interpretatiewe rol van die luisteraar verlig deur gebruik te maak van sekere linguistiese middele en verbindings- 
woorde is byvoorbeeld so ' $n$ linguistiese middel. Wanneer verbindingswoorde wel gebruik word, noem Verhagen (2001: 110), met verwysing na Matthiessen en Thompson (1988), die koherensierelasie 'n "gegrammatikaliseerde koherensierelatie".

In (3) hierbo kan die kousale verhouding deur want geleksikaliseer word:

(4) Gee bietjie die tang aan want die spyker sit nogal vas

maar ook byvoorbeeld deur naamlik:

(5) Gee bietjie die tang aan — die spyker sit naamlik nogal vas.

'n Bysin soos

(6) Ek weet dat hy siek is

bevat ' $n$ posisiegleuf wat deur die onderskikker dat geleksikaliseer kan word. Afhanklike bysinne soos in (6) vereis ' $n$ onderskikker; skoon bysinne soos

(7) Ek weet hy is siek

nie.

Wanneer verbindings sterk semanties gemarkeer is, deur byvoorbeeld ' $n$ kousale of voorwaardelike verhouding, kan die verbindingswoorde nie weggelaat word nie; hulle moet geleksikaliseer word:

(8) Jy mag nie televisie kyk voordat jy jou huiswerk gedoen het nie.

*(9) Jy mag nie televisie kyk, jy jou huiswerk gedoen het nie.

Sintakties gesproke kan verbindingswoorde gedefinieer word as woorde wat twee of meer elemente of konjunkte (sinne, frases, woordgroepe en woorde) verbind. Die aard van die verhouding tussen die konjunkte bepaal watter verbindingswoord gekies sal word, maar die keuse hou bepaalde sintaktiese gevolge in - meer hieroor in die paragraaf oor onderskikking. Verbindingswoorde kan óf beskou word dat hulle die graad van afhanklikheid tussen sinne merk, óf dat hulle optrede die gevolg is van die graad van afhanklikheid wat reeds deur die geïntegreerde sin uitgedruk word (Gouws 1998: 94). Op 'n strukturele vlak is dit die afhanklike aard van die bysin, gemerk deur afhanklike volgorde, wat die basis vorm vir die onderskeid tussen neweskikkers en onderskikkers.

Die term taksis kan as superordinaat gebruik word om die graad van interafhanklikheid tussen die klouse wat geïntegreer word aan te dui (Halliday en Matthiessen 2004: 374). Die terme parataksis en hipotaksis word gebruik om twee punte op 'n kontinuum aan te dui. Die graad van klousintegrasie is hier die maatstaf. Aan die een ent van die spektrum is daar neweskikking sonder ' $n$ bindwoord en aan die ander eindpunt inlywing by byvoorbeeld ' $n$ naam- 
woordstuk. In die volgende uiteensetting maak ons veral gebruik van Ponelis (1979), Gouws (1998) en Taylor (2002: 430 e.v.) se uiteensettings.

\subsubsection{Parataksis}

Volgens Ponelis (1979: 603) is parataktiese konstruksies 'n geslote klas wat "bestaan uit twee of meer funksioneel gelyksoortige lede (konjunkte) wat simmetries (omkeerbaar) geskakel word deur 'n verbindingsmiddel (óf jukstaposisie óf ' $n$ neweskikker)". In Afrikaans het alle klouse in 'n parataktiese konstruksie onafhanklike (hoofsin-) volgorde. Die spilwerkwoord neem die tweede posisie in die sin in, langs die onderwerp.

\subsubsection{Minimale integrasie (Neweskikking sonder verbindingswoord)}

Twee of meer klouse word gewoon jukstaposisioneel naas mekaar geplaas. Taylor (2002: 430) definieer dit as "a combinational device for lining up linguistic expressions":

(10) Hy het gekom, hy het gesien, hy het oorwin.

Die hoorder of leser lei self af wat die verband tussen die klouse is - kousaal of chronologies, byvoorbeeld. Die feit dat ikonisiteit 'n ontwerpkenmerk van taal is, veroorsaak dat (10) tipies (selfs uitsluitlik) sekwensieel geïnterpreteer sal word.

\subsubsection{Neweskikking met neweskikker}

Neweskikkers verbind sintakties gelyksoortige elemente. Elke klous kan ook onafhanklik van die ander optree:

(11) Hy kan nie die werk doen nie want hy is te oud.

Die klas neweskikkers verskil van die onderskikkers daarin dat daar by neweskikkers 'n verdere subkategorie, die korrelatiewe neweskikkers, onderskei kan word. Die prototipiese neweskikkingskonstruksie is, volgens Gouws (1998), nie-korrelatief en nie-jukstaposisioneel, gevorm deur en, maar, want, of en dog. Die tipies Afrikaanse korrelatiewe neweskikkers is: én ... én, óf ... óf, nóg ... nóg, hetsy ... hetsy, sowel ... as, beide ... en, ewemin ... as. ${ }^{4}$

(12) Jan kan óf huis toe gaan óf eers die werk klaarmaak.

Semanties onderskei die korrelatiewe neweskikkers hulle sistematies daardeur dat groter nadruk uitgedruk word deur hulle gebruik (Gouws 1992: 99). 


\subsubsection{Hipotaksis}

\subsubsection{Onderskikking}

Onderskikkers integreer sintakties ongelyksoortige elemente - 'n onafhanklike sin (die hoofsin) en 'n afhanklike sin (die bysin). Die bysin word nie slegs verstaan in terme van sy verhouding met die hoofsin nie, maar is in der waarheid afhanklik van die hoofsin vir sy interpretasie. In Afrikaans word hierdie afhanklikheid duidelik gemerk - die woordorde word aangepas sodat die spilwerkwoord uitskuif na die sinsgrens:

(13) Hy word nie gestraf nie omdat hy onskuldig is.

Voorbeelde van onderskikkers is onder andere: dat (en dat-samestellings soos nadat, totdat, voordat), of, toe, alvorens, alhoewel.

\subsubsection{Komplementsinne}

By komplementsinne word een klous ingebed in 'n ander:

(15) Ek het hulle sien inbreek.

Dit is ' $n$ komplekse kwessie, veral as gevolg van die verskillende soorte sintaktiese konstruksies wat as komplemente kan optree. Infinitiefsinne (met byvoorbeeld om, deur en ten einde en die modale partikel te) tree tipies as sulke komplemente op en soos alle komplemente is hulle noodsaaklike aanvullings by die werkwoord. Vergelyk die volgende voorbeeld:

(16) Ek hoop om jou gou weer te sien.

Die bysin in (16) met sy afhanklike volgorde is 'n komplement by die hoofsin. Mens kan immers nie net sê: *Ek hoop nie.

Geankerde komplementklouse word deur dat ingelei:

(17) Ek hoop dat ons mekaar gou weer sal sien.

Die hoogste graad van integrasie kry ons wanneer twee klouse saamsmelt tot een:

(18) Volvo's is baie duur om te onderhou.

'n Onderskeid word ook getref tussen klousintegrasie en inlywing (Halliday en Matthiessen 2004: 426), soos in

(19) Die gelukkige tye voor die oorlog begin het 
waar ' $n$ sin ingebed word by byvoorbeeld ' $n$ naamwoordstuk (en nie by ' $n$ ander klous nie).

Bogenoemde uiteensetting toon aan dat neweskikkers en onderskikkers dieselfde funksie en dikwels selfs ook dieselfde semantiese lading gemeen het, maar dat hulle duidelik nie tot dieselfde woordsoortkategorie behoort nie en dat ook subkategorisering by neweskikkers van belang is.

\section{Leksikografiese bewerking}

Aangesien onderskikkers sintakties gemerk is (in teenstelling tot neweskikkers) moet woordeboeke van hierdie basiese onderskeid rekenskap gee deur die kategorie waartoe die verbindingswoord behoort, duidelik aan te toon.

In die WAT, HAT en PVAW word neweskikkers byvoorbeeld nie kategories onderskei van onderskikkers nie - die woordsoort van beide tipes verbindingswoorde word bloot aangedui as voegwoord. Maar soos Gouws (1998: 90) met verwysing na Ponelis (1979) opmerk, is die verskille tussen onderskikkers en neweskikkers so ingrypend dat dit onverantwoordelik is om hulle as lede van dieselfde woordsoortelike kategorie te beskou.

Voorts behoort die eiesoortige semantiese aard van hierdie groep woorde ook neerslag te vind in die artikelstruktuur. Dit is te betwyfel of daar op dieselfde manier van polisemiese onderskeidings sprake is as by leksikale morfeme. Semantiese inligting behoort nie as deel van die definiens aangebied te word nie en die kernfokus behoort nie betekenisverklaring (ons beklemtoning) te wees nie (Gouws 1992: 99). Dat korrelatiewe neweskikkers byvoorbeeld duidelik nadruk uitdruk, behoort eksplisiet genoem te word. Meer grammatiese inligting as wat tans aangebied word, moet gegee word.

Gouws (1992) het reeds aangetoon dat dat daar nie voorsiening gemaak word vir 'n alternatiewe artikelstruktuur vir verbindingswoorde nie. Funksiewoorde vra om ' $n$ ander artikelinkleding as leksikale morfeme met 'n eiesoortige mikrostrukturele bewerking. In die onderhawige uiteensetting stel ons ' $n$ alternatiewe leksikografiese bewerking van verbindingswoorde in 'n aanleerderwoordeboek voor. Die beginsels wat toegepas word, is volgens ons egter ewe geldig ook vir verklarende woordeboeke. Aangesien die funksie van verbindingswoorde baie prominent aangedui behoort te word, stel ons voor dat die mikrostruktuur van die woordeboekartikel dit reflekteer.

\subsection{Makrostrukturele bewerking}

Grammatikale inligting kan op verskillende plekke in 'n woordeboek aangebied word. Macmillan English Dictionary For Advanced Learners bevat byvoorbeeld heelwat grammatikale inligting op die skutblad en middelteks (tussen $m$ en $n$ ) van die woordeboek en daar is baie hiervoor te sê. In die WAT en die verklarende handwoordeboeke word 'n mate van grammatikale leiding gegee in 
die gebruikersinligtinggedeelte. Om toegang tot inligting oor veral woordvolgorde-implikasies te vergemaklik, is 'n eerste aanbeveling dat die newe- en onderskikkerlemmas voldoende sintaktiese inligting sal verskaf met voorbeelde wat ook die gebruik oor sinsgrense heen sal illustreer.

Voegwoord as aanduiding van woordkategorie moet vermy word. In die gebruiksinligting kan daar verwys word na die vroeëre gebruik van die term. ${ }^{5}$

Sowel eenwoordneweskikkers as meerwoordige neweskikkers soos sowel as moet lemmastatus kry (vergelyk Gouws 1992).

Korrelatiewe neweskikkers moet as lemmas gelys word.

\subsection{Mikrostrukturele bewerking}

By elke newe- en onderskikker moet daar 'n kruisverwysing wees na die lemmata neweskikker en onderskikker. By die inskrywings onder hierdie lemmata moet daar genoeg leiding wees rakende die sintaktiese konsekwensies van dié tipe verbindingswoord, soos vervolgens aangedui sal word. (Dit geld ook voegende bywoorde wat nie in hierdie artikel bespreek word nie.) Wat voorbeeldsinne betref, moet daar afgewyk word van die bestaande praktyk. Die sinne moet die sintaksis en die gevolge van die gebruik van 'n newe- alternatiewelik onderskikker baie duidelik illustreer, en nie sinne wees waarin die gebruik van die trefwoord, naamlik newe- of onderskikker, geïllustreer word nie.

\section{Neweskikker}

'n Neweskikker verbind woorde (penne, potlode en uitveërs), woordgroepe (blaffende honde en miaauende katte) en sinne (Die hond blaf en die kat miaau) wat gelyke status het. Neweskikkers affekteer nie die volgorde van die sin wat volg op die neweskikker nie. Die sinne behou hulle onafhanklike woordorde en die eerste werkwoord in die sin verander nie van posisie nie. Die hond blaf en die kat miaau.

Die neweskikkers (enkelwoorde) in Afrikaans is: en, maar, want, of, dog.

Kyk ook: korrelatiewe neweskikker.

\section{Korrelatiewe neweskikker}

Korrelatiewe neweskikkers bestaan almal uit twee lede wat saam as neweskikker optree: óf ... óf, én ... én, beide ... en, sowel ... as, nóg ... nóg, nie alleen ... nie, maar ook

Óf Jan óf Piet gaan met Marie trou.

Nóg hy nóg sy suster was by die begrafnis.

Nie alleen het sy die eksamen gedruip nie, maar ook haar kar afgeskryf.

\section{Onderskikker}

'n Onderskikker lyf 'n bysin by 'n hoofsin in. Die bysin verkry afhanklike woordorde. Die posisie van die eerste werkwoord in die sin verander - dit skuif na agter:

Ons het geweet dat alles nie pluis was nie.

Aangesien dit vandag bitter koud is, sal daar nie swemles wees nie. 


\section{5. 'n Bespreking van dat}

\subsection{Die hantering van dat in $B A, W A T$ en $H A T$}

\subsection{1 $B A$}

In $B A$ dui die voorbeelde sekere tipiese gebruike van dat-klouse en die hoofsinne wat hulle voorafgaan, aan, bv. Dit is jammer dat die motor langs die pad ingegee het. Hier word die tipiese patroon van 'n voorlopige onderwerp plus koppelwerkwoord plus adjektief plus res geillustreer, maar nêrens word aangedui dat die voorlopige dit soms opsioneel is nie, bv. Jammer dat ek laat is. Twee voorbeeldsinne dui aan dat dat-klouse voorafgegaan kan word deur ' $n$ hoofsin wat die spreker se opinie oor iets aandui. Dit sou waarskynlik voordeliger wees om eerder 'n ander tipiese patroon ook te illustreer, waar ' $n$ feit aangedui word, bv. Dit is ' $n$ feit dat hy diabetes het. Ander patrone, bv. die negatiewe bevelsvorm word wel geillustreer, maar die voorbeelde in $B A$ het geen vetgedrukte woorde in wat gebruikers kan help om tipiese leksikale patrone te identifiseer nie.

\subsubsection{WAT}

Die hoofprobleem met die hantering van dat in die WAT is die informasiedigtheid en die probleem om 'n spesifieke tipe gebruik van dat op te spoor. Dit sou sin maak om 'n kort uiteensetting van die hoofgebruike te gee, soos wat die Macmillan Advanced Learner's Dictionary met lemmas met 'n hoë informasiedigtheid doen. Op hierdie manier kan beide die gebruiker wat slegs 'n vinnige oorsig wil hê en die gebruiker wat meer intensiewe en tydsame studie wil doen, gehelp word. (Terselfdertyd moet verouderde gebruike in 'n nuwe uitgawe verwyder word.) Daar kan byvoorbeeld twee dinge oor dat genoem word voor die uitvoerige bespreking, naamlik dat dat as 'n onderskikker en aanwysende voornaamwoord gebruik kan word.

\subsubsection{HAT}

Alhoewel HAT nie so ' $n$ hoë informasiedigtheid as WAT het nie, sal die gemiddelde gebruiker waarskynlik nie weet wat 'n naamwoordelike bysin en ' $n$ bywoordelike bysin beteken nie en hulle sal waarskynlik slegs baat vind by die voorbeelde wat tipiese gebruik illustreer.

\subsection{Voorgestelde bewerking in 'n gevorderde aanleerderwoordeboek}

dat - onderskikker [Kyk onderskikker]

Dat word as 'n onderskikker gebruik om twee sinne met mekaar te verbind. Die 
werkwoord verskuif na agter in die sin, bv. Ek het nie geweet dat hy in die tronk was nie.

1. Dat word gebruik om 'n stelling, feit, idee of rede in te lei: 1.1 gebruik om in 'n stelling te wys wat iemand sê, dink, glo, ens.: Sy sê dat sy nie lekker voel nie.- Ek dink dat sy poging heel goed was. - Jan glo dat sy vrou ontvoer is. - Daar is gesuggereer dat ek die wasgoed moet was. 1.2 gebruik om 'n sin te begin wat 'n feit aandui: Ons kan nie die feit ignoreer dat so baie jongmense werkloos is nie. -Dat niemand haar in die hospitaal besoek het nie, is 'n skande. - Dit is verstommend/verbasend/interessant/belangrik dat: Dit is verstommend dat hy elke keer dieselfde fout maak. Dit was belangrik dat hy warm gehou moes word. 1.3 gebruik om te verduidelik hoekom iemand bly, hartseer, kwaad, ensovoorts voel: $E k$ is só bly dat ek jou weer raakgeloop het. Hy was so kwaad dat hy amper die skelm geskiet het. Ek is jammer dat ek laat is.

Wanneer dat nie 'n sin begin nie, word dit dikwels weggelaat, veral as mens praat: Ek sê mos ek is nie lus nie. Let op die verskuiwing van die werkwoord na agter in die sin wanneer dat wel gebruik word.

2. gebruik na so of sulke om die resultaat van iets aan te dui: Sy woorde was so kwaai dat sy begin huil het. Kyk so ... dat en sulke ... dat.

Die onderskikker dat word dikwels weggelaat in uitdrukkings met so of sulke, veral wanneer mens praat. Sy was so bang — sy kon nie beweeg nie.

\section{6. 'n Bespreking van of en óf ... óf}

\subsection{Die hantering van of in $B A, H A T$, WAT en PVAW}

Om mee te begin, verskil ons van Bosch (1997: 35) wat stel: "Of kan beide as neweskikker (Engels or) en as onderskikker (Engels if, whether, as if ) funksioneer". Selfs meer bedenklik is haar gevolgtrekking nadat sy die neweskikker of bespreek het: "Of ... tree op in die tussengebied tussen neweskikking en onderskikking en (is) die enigste voegwoord wat uitgebreid ook suiwer onderskikkende verband kan aandui" (Bosch 1997: 43). Hierdie standpunt, naamlik dat daar net een "voegwoord" of is, word weerspieël in die manier waarop of in die WAT, die HAT en Pharos VAW hanteer word - 'n werkwyse wat leksikologies, kategoriaal en semanties onaanvaarbaar is (Gouws 1992: 93). Die drie genoemde woordeboeke hanteer die twee ofs, wat duidelik lede is van ' $n$ homonimiese paar, as een polisemiese lemma met as kategorie-aanduiding voegwoord, of, in die geval van $P V A W$, as 'n modaliteitswoord (wat dit ook mag beteken). In die mikrostruktuur van die genoemde woordeboeke word 'n hele aantal polisemiese waardes gelys asof hierdie waardes aan mekaar verwant is. $B A$ volg hier baie beter leksikografiese praktyk deur sowel die neweskikker of as die onderskikker as aparte lemmas te lys en hulle woordsoortkategorie ook duidelik so aan te dui. 
Kruisverwysing in die verklarende woordeboeke onder bespreking is ook problematies. Die lemma voegwoord is vanselfsprekend nog nie in die WAT opgeneem nie, maar ook in die HAT en $P V A W$ sal 'n gebruiker min of selfs geen leiding hier kry nie (die lemma modaliteitswoord verskyn nie in PVAW nie). $B A$ gebruik nie die term as aanduider van die woordsoort nie en het daarom ook nie nodig om dit as lemma op te neem nie.

In WAT, HAT en PVAW word die funksie telkens aangedui as sou dit saamhang met ' $n$ polisemiese onderskeiding. Die WAT begin byvoorbeeld elke polisemiese onderskeiding met die frases ter verbinding van of ter inleiding van. Dit is duidelik dat dit besonder moeilik is om die betekenis van of telkens te parafraseer en baie lang en omslagtige verduidelikings volg. Daar word wel gebruik gemaak van die tipiese verbande wat deur verbindingswoorde uitgedruk word. Waar dit moontlik is, word ' $n$ sinoniem of woordgroep gegee vergelyk byvoorbeeld $1 \mathrm{a}, 1 \mathrm{~b}$ en $3 \mathrm{a}$ by of in WAT Deel XI.

Daar moet baie goed besin word oor die uitdrukkings wat in die WAT onder die lemma of opgeneem is. Die korrelatiewe neweskikker óf ... óf behoort aparte lemmastatus te kry, soos alle neweskikkers van hierdie tipe. Of so en of wat (in die betekenis "by benadering geskat") kan opgeneem word by die neweskikker ${ }^{1}$ of (4b) en of .. of (nie) by die onderskikker of (4).

\subsection{Voorgestelde bewerking van of in 'n gevorderde aanleerderwoorde- boek}

${ }_{1}$ of neweskikker [Kyk neweskikker]

Of word gebruik om woorde, sinsdele of sinne te verbind.

1. 'n Teenstellende of alternatiewe verband word uitgedruk.

a. Daar moet tussen moontlikhede of keuses gekies word:

Drink jy tee of koffie?

Jy kan leer vir die eksamen of televisie kyk.

In 'n lysie word of voor die laaste moontlikheid gebruik: Wil jy tee, koffie of 'n sappie hê?

Die dele wat verbind word, kan omgeruil word:

Drink jy koffie of tee?

Jy kan televisie kyk of leer vir die eksamen.

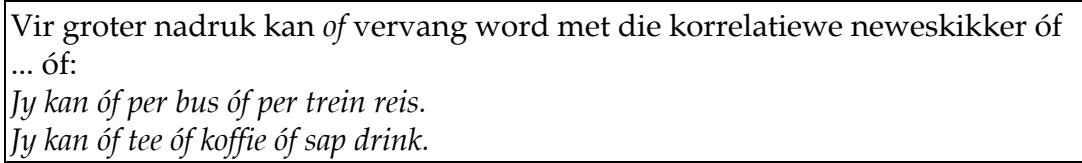

b. Daar is meer as een moontlikheid, maar die een hoef die ander nie uit te sluit nie. 6

Elke middag kuier sy by ons of ons by haar.

Kan ek vir jou tee of koffie gee? 
Die dele wat verbind word, kan omgeruil word:

Kan ek vir jou koffie of tee gee?

c. Dit dui aan dat die spreker onseker is:

Sy gaan met Jan of Piet trou, ek weet nie mooi met wie nie.

2.a. Dit druk eendersheid van betekenis uit met byvoorbeeld 'n sinoniem of vervangende woorde:

Die vakgebied staan as chemie of skeikunde bekend.

b. Dit korrigeer, verduidelik of verklaar 'n woord of frase, of liewer:

Die tekeninge of ruwe sketse is baie haastig gemaak.

3. Dit verbind 'n opdrag of bevel met 'n dreigement:

Staan of ek skiet!

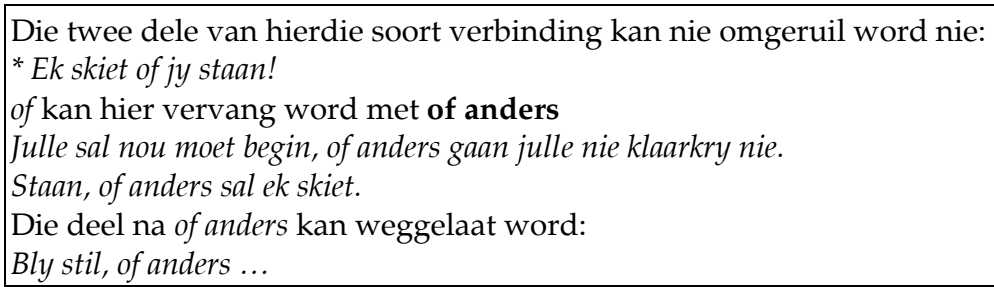

4.a. Dit verbind 'n naamwoord en telwoord sodat 'n onbepaalde tydsperiode of hoeveelheid uitgedruk word:

' $n$ dag of twee; ' $n$ stuk of tien; ' $n$ keer of drie

b. Dit verbind met so of wat sodat 'n onbepaalde tydsperiode of hoeveelheid uitgedruk word:

Gee my net 'n minuut of wat.

Dit het onder die 100 of so papiere op haar lessenaar gelê.

5. Dit word gebruik om iets of iemand in te sluit in 'n negatiewe stelling, en nie: Ek het vandag nog nie nat of droog oor my lippe gehad nie.

IDIOMATIESE UITDRUKKINGS (met hulle verklarings)

Sy het nie kind of kraai nie

Sonder om te blik of te bloos

Ek kan nie kop of stert uitmaak van wat hy sê nie

6. Dit word gebruik om 'n rede te gee vir jou opinie:

Hy het geen idee waar die plek is nie, of hy sou nie so verkeerd gery het nie.

7. Dit dui aan dat iets normaalweg die geval is:

Hy is nooit in 'n wedstryd nie, of hy speel vuil.

${ }^{2}$ of onderskikker [Kyk onderskikker]

Of lei 'n bysin in by 'n hoofsin.

1. Die bysin druk twyfel of onsekerheid uit en beteken "wat is die moontlikheid dat?". Dit volg dikwels na die werkwoord wonder:

Hy wonder of hy die eerste rugbyspan sal haal. Of hy nog president sal word, kan ek nie sê nie.

2. of lei 'n vraag in wat bevestigend of ontkennend beantwoord kan word: Weet jy al of julle die naweek see toe sal gaan? 
3. of lei bysinne in wat vergelyking uitdruk, asof:

Dit volg tipies na 'n koppelwerkwoord soos lyk, voel, maak, is, blyk, voorkom, klink, voel, smaak, ruik.

Die bysin na die koppelwerkwoord kan soms afhanklike en soms onafhank-
like volgorde hê:
Hy lyk of hy flou wil word. (afhanklike volgorde)
Hy lyk of hy wil flou word. (onafhanklike volgorde)
maar nie altyd nie.
Dit voel vir my of die winter vanjaar besonder vroeg gekom het. (net afhanklike
volgorde)
Dit is of ek jou net gister laas gesien het. (net afhanklike volgorde)

4. Saam met of (nie) dui dit aan dat iets sal gebeur of so sal wees al gebeur enigeen van die alternatiewe:

Of julle vandag vertrek of môre, julle sal nog steeds betyds wees.

Gee julle antwoorde in of julle nou klaar is of nie.

Die sinne kan verkort word en die of (nie) kan weggelaat word:

Wen of verloor, die span is reeds in die eindstryd. [Vergelyk: of hulle môre sal wen of verloor ...]

Verwaand of nie, ek hou van hom [in plaas van of hy verwaand is of nie ...].

${ }^{3}$ of neweskikker [Kyk neweskikker]

Of verbind twee sinne

1. Die sin met of volg na 'n stelling en is 'n vraag: Hy is weg, of weet jy dit nie?

Let hier op die inversie (omruiling) van die onderwerp en werkwoord na of.

2. Die sin met of volg na 'n stelling en bevraagteken of korrigeer dié stelling: Ons sal ten minste gedeeltelik die pad van die res van Afrika loop — of so meen oorsese sakelui.

Sy oefen in die geheim. Of so het sy gedink.

\subsection{Die korrelatiewe neweskikker óf ... óf}

Hierdie neweskikker het wel lemmastatus in HAT en $B A$, maar nie in PVAW of WAT Deel XI nie. Soos al die ander korrelatiewe neweskikkers, behoort dit apart hanteer te word. Die belangrikste semantiese inligting wat gegee behoort te word, is dat die keuse beklemtoon word.

\section{Gevolgtrekking}

Hoewel Gouws (1992) reeds op verskeie leemtes in die hantering van voegwoorde in verskillende eentalige woordeboeke gewys het, het baie min van sy voorstelle tot hul reg gekom in Afrikaanse woordeboeke. In hierdie artikel is van sy voorstelle herbevestig deur 'n teoretiese begronding en daarop voort- 
gebou deur onder andere voorstelle vir die hantering in 'n aanleerderwoordeboek van die onderskikker dat en die homonimiese verbinder of.

\section{Aantekeninge}

1. Vergelyk Carstens (1997: 263) vir 'n uitvoerige lys terme.

2. Vergelyk hier byvoorbeeld Carstens en Van de Poel (2010: 338) wat dié term nog in sy tradisionele betekenis en sonder kommentaar gebruik as 'n soort superordinaat vir sowel neweskikkers as onderskikkers en voegende bywoorde, as sou hulle onproblematies tot dieselfde woordsoortelike kategorie behoort.

3. Die gebruik van verbindingswoorde is maar een van die maniere waarop kohesie in ' $n$ teks bewerkstellig kan word. Ander kohesiemerkers is byvoorbeeld verwysing met behulp van anafore, tydadjunkte soos Iater, toe, eers en intussen, verskillende tipes leksikale kohesie (herhaling, sinonimie, ens.) en diskoersmerkers soos gambiete, byvoorbeeld.

4. Gouws (1992: 95) onderskei in der waarheid vier subtipes hier.

5. Ons is bewus daarvan dat hierdie term in skoolhandboeke en deur die Departement van Basiese Onderwys gebruik word. Dit is onses insiens egter reeds lankal nodig dat daarop gewys moet word dat baie van die terminologie wat deur die Departement gebruik word verouderd is en dikwels ook verkeerd verstaan word deur die outeurs van sommige skoolhandboeke. Die voorbeeld van $B A$ in hulle "Wenke vir die gebruiker" kan eerder nagevolg word.

6. In 'n elektroniese woordeboek kan die verskil in intonasie tussen eksklusiewe disjunksie 1(a) en nie-ekslusiewe disjunksie 1(b) met 'n klankgreep geillustreer word. In 1(b) sal daar neutrale (gelyke) klem op die twee konjunkte wees, in 1(a) sal elk van die moontlikhede beklemtoon word.

\section{Verwysings}

\section{Woordeboeke}

Gouws, Rufus et al. (Reds.). 1994. Basiswoordeboek van Afrikaans. Pretoria: J.L. van Schaik.

Labuschagne, F.J. en L.C. Eksteen. 2010. Pharos Verklarende Afrikaanse Woordeboek. Kaapstad: Pharos Woordeboeke.

Odendal, F.F. en R.H. Gouws. 2005. HAT. Verklarende Handwoordeboek van die Afrikaanse Taal. Kaapstad: Pearson Education South Africa.

Rundell, Michael en Gwyneth Fox (Reds.). 2002. Macmillan English Dictionary for Advanced Learners. Oxford: Macmillan.

Schoonees, P.C. (Hoofred.). 1956. Woordeboek van die Afrikaanse Taal. Tweede Deel: D-F. Derde Oplaag. Pretoria: Die Staatsdrukker.

Van Schalkwyk, D.J. (Hoofred.). 2000. Woordeboek van die Afrikaanse Taal. Deel XI: N-O. Stellenbosch: Buro van die WAT. 


\section{Ander bronne}

Al-Kasimi, A.M. 1977. Linguistics and Bilingual Dictionaries. Leiden: E.J. Brill.

Béjoint, H. 2000. Modern Lexicography: An Introduction. Oxford: Oxford University Press.

Blühdorn, H. 2008. Subordination and Coordination in Syntax, Semantics and Discourse. FabriciusHansen, Catherine en Wiebke Ramm (Reds.). 2008. 'Subordination' versus 'Coordination' in Sentence and Text: 59-85. Amsterdam: Benjamins.

Bosch, Barbara. 1984. 'n Sintaktiese ondersoek na die gebruik van onderskikkende voegwoorde en sinsverbindende woorde in Afrikaans. Ongepubliseerde doktorale proefskrif, Rhodes Universiteit, Grahamstad.

Bosch, Barbara. 1997. Die voegwoord of. Suid-Afrikaanse Tydskrif vir Taalkunde 15(2): 35-44.

Bosch, Barbara. 1998. Die onderskikker dat: 'n korpus-gebaseerde bespreking. (Deel 1). SuidAfrikaanse Tydskrif vir Taalkunde 16(4): 120-126.

Carstens, W.A.M. 1997. Afrikaanse tekslinguistiek: 'n inleiding. Pretoria: J.L. van Schaik.

Carstens, W.A.M. en Kris van de Poel. 2010. Teksredaksie. Stellenbosch: SUN MeDIA.

De Villiers, M. 1983. Afrikaanse grammatika vir volwassenes. Goodwood: Nasou.

Gouws, R.H. 1989. Leksikografie. Pretoria en Kaapstad: Academica.

Gouws, R.H. 1992. Die leksikografiese bewerking van neweskikkers. Tydskrif vir Geesteswetenskappe 32(2): 91-103.

Gouws, R.H. 1998. Neweskikkers in Afrikaans: sintaktiese en semantiese opmerkings. Gouws, Rufus en Ilse Feinauer (Reds.). 1998: 89-100.

Gouws, Rufus en Ilse Feinauer (Reds.). 1998. Sintaksis op die voorgrond. Pretoria: J.L. van Schaik.

Halliday, M.A.K. en R. Hasan (Reds.). 1976. Cohesion in English. Londen: Longman.

Halliday, M.A.K. en C.M.I.M. Matthiessen. 2004. An Introduction to Functional Grammar. Derde Uitgawe. Londen: Arnold.

Hartmann, R.R.K. 1982. Das zweisprachige Wörterbuch im Fremdsprachenerwerb. Wiegand, H.E. (Red.). 1982: 73-86.

Hartmann, R.R.K. (Red.). 1984. LEXeter' 83 Proceedings. Tübingen: Max Niemeyer.

Langacker, R.W. 1987. Foundations of Cognitive Grammar Vol. I. Stanford: Stanford University Press.

Matthiessen, C. en S.A. Thompson. 1988. The Structure of Discourse and 'Subordination'. Haiman, J. en S.A. Thompson. (Reds). 1988. Clause Combining in Grammar and Discourse: 275-329. Amsterdam: John Benjamins.

Ponelis, F.A. 1979. Afrikaanse Sintaksis. Pretoria: J.L. van Schaik.

Sinclair, J.M. 1984. Lexicography as an Academic Subject. Hartmann, R.R.K. (Red.). 1984: 3-12.

Taylor, J.R. 2002. Cognitive Grammar. Oxford: Oxford University Press.

Verhagen, A. 2001. Terug naar want en omdat. Dongelmans, B.P.M., J.A. Lalleman en O.J. Praamstra (Red.). 2001. Kerven in een rots. Opstellen over Nederlandse taalkunde, letterkunde en cultuur, aangeboden aan Jan W. de Vries bij zijn afscheid als hoogleraar Dutch Studies aan de Universiteit Leiden: 107-119. Leiden: Stichting Neerlandistiek Leiden.

Wiegand, H.E. (Red.). 1982. Germanistische Linguistik 3-6/80. Hildesheim: Georg Olms Verlag. Wybenga, D.M. (Red.). 1989. Taalkompas: elke student se gids. Pretoria: Serva. 